\title{
BIAS-BIASDIKOTOMI DALAM BUKU AJAR MATAKULIAH PENDIDIKAN AGAMA ISLAM DI PERGURUAN TINGGI UMUM
}

\author{
Yusuf Hanafi*
}

\begin{abstract}
A bstract: Thekind of Islamicsienes being taught in many higher education institutes in Indonesiaisthat whichtendstomakestudantsisdatedfromther word TheseIsamicsiences in themserves arekind of sqparation from therdigiaus and worddy, Idamicand seeular. This didhtomous dharader had inflicted upon thestudents mentality, who in tum become equally didhtomous in thir attitude, and way of thinking This paper tries to explore this and attempts to sek thebeet way in which the dichotomas amialumcan bereplaced with the integrativeone It argues that, likethenature of Idam reigiaus scienes cannot besqparated fromthenon-rigigousones Theonemist work handinhand with theothersothat. Thepaper addresess speifically thedilemmasintrinsicuithin thetext book used bymany higher religias institutes in the country called "Reorientas Pendidikan Islam Menuju Pengenbangan KepribadianInsan Kamil". Thebook - weargue dreetsthesudantstoadqpt a singeidantity, disregarding therefore themilti and diveseracial, reigiaus and even altural bedkgaund of thestudents. The paper is simply abat a waming of the danger of theimplication that the book can comeup

Keywords: Diffractions, didhatamy, Islamicstudies, Idamiceduration
\end{abstract}

\section{Pendahuluan}

Pemilahan secara dikotomis antara keilmuan agama dan keilmuan umum mengakibatkan kajian-kajian keislaman menjadi kaku sehingga kurang responsif terhadap tantangan dan tuntutan perkembangan zaman. Terlebih lagi jika pandangan-pandangan dan analisis-analisisnya tidak memahami, mempertimbangkan atau menyertakan sama sekali bagaimana sesungguhnya diskursus kontemporer tentang politik, ekonomi, sosial, budaya, dan sains. ${ }^{1}$

Belakangan banyak muncul keluhan terhadap lulusan perguruan tinggi yang hanya mengetahui soal-soal "normativitas" agama semata, namun kesulitan memahami "historisitas" agama sendiri, lebih-lebih historisitas agama orang lain. Belum lagi masuk kepada persoalan pokok tentang perpaduan antara "ilmu" dan "agama". A pakah mengikuti model singeentitydalam arti pengetahuan agama berdiri sendiri tanpa memerlukan bantuan metodologi yang digunakan oleh ilmu pengetahuan umum yang lain, dan begitu pula sebaliknya. ${ }^{2}$

\footnotetext{
"Universitas Negeri Malang E-mail: sufi_rmi@yahoo.com dan doktor.sufi@ gmail.com. Telp. 081334111537.

${ }^{1}$ Baca A bdullahi Ahmed al-Na'im,. Tonardan IsamicReomation Civil Libeties, HumanRight andIntemational Law (New York: Syracuse University Press, 1990).

${ }^{2}$ Periksa Mohammed Arkoun, Taikhiyjatal-Fikral-'Arabi al-Idami,ter. Hashim Salih (Beirut: Markaz al-Inma' alQ awmi>1986). Telaah pula G regory Baum, AgamadalamBayanghbayangIrdativisme SeluahAnalisis Sosidog Pengtahuan Karl Mannhim tentangSintesa Kebnaran HistansNormatif, terj. Achmad Mustajib e.al. (Yogyakarta: PT. Tiara Wacana, 1999).
} 


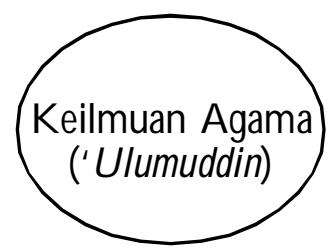

\section{Gambar 1 - Paradigma SingeEntity}

A taukah mengikuti model isdatedentitiesdalam arti masing-masing rumpun ilmu berdiri sendiri, tahu keberadaan rumpun ilmu yang lain, tetapi tidak bersentuhan dan bertegur-sapa secara metodologis.

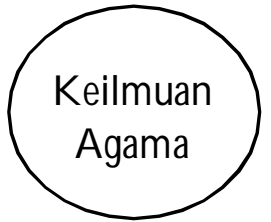

('Ulumuddin)

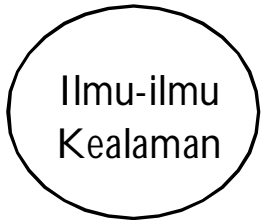

(Natural Säenes)

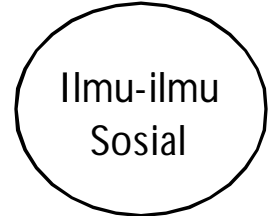

(Soial Scienes)

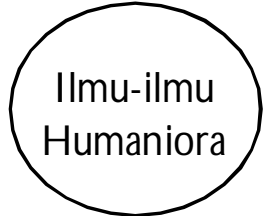

(Humanities)

\section{Gambar 2 - Paradigma Isdated Entities}

A tau model inteccoeted entities, dalam arti masing-masing sadar akan keterbatasannya dalam memecahkan persoalan manusia, lalu menjalin kerjasama setidaknya dalam hal yang menyentuh persoalan pendekatan (approad), metode berpikir, dan penelitian (process and procedure)

Keilmuan Agama

('Ulumuddin)

Ilmu-ilmu Sosial

(Social Saienes)

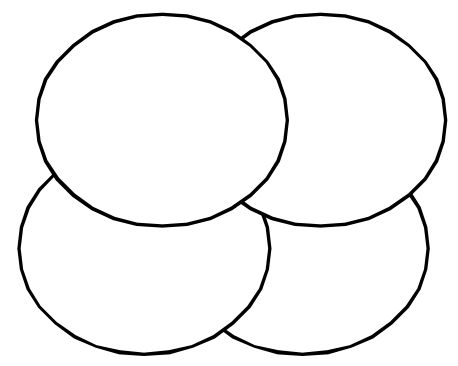

Ilmu-ilmu Kealaman

(Natural Saienes)

Ilmu-ilmu Humaniora

(Humanities)

Gambar 3 - Paradigma Interconeted Entities 3

Ironisnya, silabus matakuliah Pendidikan Agama Islam (PAI) yang dikembangkan di Perguruan Tinggi Umum (PTU) justru mencerminkan paradigma dikotomis-atomistik yang memandang bidang keilmuannya sebagai disiplin keilmuan mandiri (singe entity) - atau setidaknya menjaga jarak dan kontak dari disiplin-disiplin keilmuan lain (isdated entities). Karenanya, kesadaran untuk membenahi dan menyembuhkan "luka-luka dikotomi" keilmuan agama dan keilmuan umum yang makin hari kian menyakitkan merupakan tuntutan yang mendesak. Proyek reintegrasi epistemologi keilmuan agama dan keilmuan umum mengandung

${ }^{3}$ M. Amin Abdullah, "D esain Pengembangan Akademik IAIN Menuju UIN: D ari Pendekatan DikotomisAtomistik ke Integratif-Interkonektif" dalam Fahruddin Faiz (ed), Isamic Studies dalam Paradigna IntegrasIntekkondks: SebuahAntdog (Yogyakarta: Penerbit SUKA Press, 2007), 98. 
arti perlunya dialog dan kerjasama antara disiplin ilmu agama dan disiplin ilmu umum yang lebih erat di masa yang akan datang. Pendekatan intedidpinarydikedepankan, interkoneksitas dan sensitivitas antarberbagai disiplin ilmu agama (reigias studies) dengan disiplin ilmu kealaman (natural saiences), disiplin ilmu sosial (social sciences), dan disiplin ilmu humaniora (humanities) perlu diupayakan secara terus-menerus tanpa henti.

Bukan eranya lagi disiplin ilmu agama (termasuk matakuliah PAI di PTU) menyendiri dan steril dari kontak dan intervensi ilmu-ilmu kealaman, ilmu-ilmu sosial, dan humaniora. Studi tentang agama (termasuk matakuliah PAI di PTU) akan sungguh-sungguh menderita, jika pandangan-pandangan dan analisis-analisisnya tidak memahami, mempertimbangkan atau menyertakan sama sekali bagaimana sesungguhnya diskursus tentang politik, ekonomi, sosial, budaya, dan seni. Sebab aspek-aspek tersebut memiliki pengaruh yang luar biasa terhadap tampilan matakuliah PAI, dan begitu pula sebaliknya. Oleh karena itu, dalam menyusun ulang kurikulum, silabi serta bahan ajar matakuliah PAI di PTU dengan etos dan nafas reintegrasi epistemologi keilmuan, prinsip-prinsip dasar yang harus dipertimbangkan

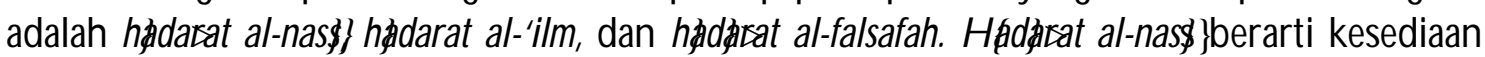
untuk menimbang kandungan isi teks keagamaan (keislaman); hadarat al-ilmberarti kesediaan untuk profesional-obyektif-inovatif dalam bidang keilmuan yang digeluti; dan terakhir hadarat al-falsafah berarti kesediaan untuk mengaitkan muatan keilmuan (yang didapat dari hadarat al-ilmdan telah "berdialog" dengan hodaratal-nasp) dengan tanggung jawab moral-etik dalam praksis kehidupan riil di tengah masyarakat. Hádarat al-nass/adalah jaminan identitas keislaman, hodarat al-ilmadalah jaminan profesionalitas-ilmiah, dan hadarat al-falsafah adalah jaminan bahwa muatan keilmuan yang dikembangkan bukan "menara gading" yang terhenti di "langit akademik", tetapi memberi kontribusi positif-emansipatif yang nyata dalam kehidupan masyarakat. ${ }^{4}$

Berpijak atas kerangka berpikir tersebut, penelitian ini dimaksudkan untuk menelaah bangunan epistemologi keilmuan dari buku ajar matakuliah PAI di Universitas Negeri Malang (UM). Sebagai catatan, sejak tahun akademik 2006-2007, pembelajaran matakuliah PAI di Universitas Negeri Malang (UM) menggunakan buku ajar (text book) Reorietasi Pendidkan Isam Menuju Pengenbangan Kepibadan Insan Kamil yang ditulis oleh tim dosen PAI UM yang berjumlah 11 orang dengan mengacu kepada kurikulum yang diterbitkan oleh D epartemen Pendidikan Nasional tahun 2002 tentang Matakuliah Pendidikan Agama Islam (PAI) bagi Perguruan Tinggi Umum (PTU). Namun dari kajian awal yang dilakukan peneliti (sebagai kontributor sekaligus editor buku ajar PAI tersebut), bias-bias dikotomi antara keilmuan agama dan keilmuan umum dapat diketemukan dengan cukup kentara dalam beberapa bagian buku itu.

Telaah awal secara selintas terhadap buku ajar matakuliah PAI di UM tersebut di atas semakin mempertegas perlunya penelitian yang sungguh-sungguh untuk mengidentifikasi bias-bias dikotomi antara keilmuan agama dan keilmuan umum dalam text book yang berusia lima tahun tersebut. Ini penting mengingat tabiat dari paradigma dikotomis yang cenderung mengisolasi bahkan mengasingkan diri dari disiplin-disiplin keilmuan lain. Padahal buku ajar matakuliah PAI untuk PTU- yang peserta didiknya berasal dari beragam rumpun

${ }^{4}$ Ibid., 36. 
keilmuan: eksakta, sosial, dan humaniora - idealnya dijiwai oleh etos dan nafas reintegrasi epistemologi keilmuan agama (reigias studies) dan umum (natural sienes, soial saienes, dan humanities). Yakni, buku ajar yang dibangun di atas paradigma interconeted entities - sadar atas keterbatasannnya dalam memecahkan persoalan-persoalan kemanusiaan, lalu menjalin kerjasama setidaknya dalam hal yang menyentuh persoalan pendekatan (approad), metode berpikir dan penelitian (process and procedre). ${ }^{5}$

Jika idealisme ini terwujud, nantinya diharapkan sajian matakuliah PAI (yang termasuk rumpun Matakuliah Pengembangan Kepribadian [MPK] dalam kurikulum inti dan diajarkan di semua fakultas) dapat menyentuh dan menyapa secara metodologis disiplin keilmuan para peserta didiknya yang beragam, sehingga pada gilirannya mereka dapat merasakan kebermaknaannya, baik dalam proses belajar-mengajar di kelas maupun saat memasuki dunia kerja kelak. Atas dasar filosofi dan kegelisahan akademik di atas itulah, penelitian yang berjudul "Bias-Bias Dikotomi antara Keilmuan Agama dan Keilmuan Umum dalam Buku Ajar Matakuliah Pendidikan Agama Islam di Universitas Negeri Malang” dipandang penting untuk dilaksanakan.

Pemilahan secara dikotomis antara keilmuan agama dan keilmuan umum mengakibatkan kajian-kajian keislaman menjadi kaku sehingga kurang responsif terhadap tantangan dan tuntutan perkembangan zaman. Terlebih jika pandangan-pandangan dan analisis-analisisnya tidak memahami, mempertimbangkan atau menyertakan sama sekali bagaimana sesungguhnya diskursus kontemporer tentang politik, ekonomi, sosial, budaya, dan sains. ${ }^{6}$

Ironisnya, bangunan epistemologi keilmuan dari textbook matakuliah PAI di Universitas Negeri Malang, yakni buku Reonientasi Pendidikan Islam Menuju Pengenbangan Kepribadian Insan Kamil- berdasarkan telaah awal peneliti- disinyalir justru mencerminkan paradigma dikotomis dengan model kajian singeentity atau setidaknya isdated entities (padahal idealnya: inteconeted enities). Oleh karena itu, permasalahan yang akan dijawab melalui penelitian ini adalah adakah bias-bias dikotomi antara keilmuan agama dan keilmuan umum dalam buku ajar matakuliah Pendidikan Agama Islam (PAI) di Universitas Negeri Malang (UM) itu.

Secara khusus, permasalahan tersebut akan dirinci sebagai berikut. Petama, apakah kajian-kajian keislaman dalam buku ajar matakuliah PAI di UM yang berjudul Reorietasi Pendidikan Islam Menuju Pengembangan Kepribadian Insan Kamil dikonstruksi secara interdisipliner ataukah sebaliknya secara dikotomis? Kedua, bagian-bagian manakah dari buku ajar matakuliah PAI di UM berjudul Reriertas Pendidkan Isam Menju Pengerbangan Kepribadan Insan Kamil yang mencerminkan paradigma dikotomis itu?

Tujuan yang hendak dicapai melalui penelitian literatur ini adalah teridentifikasinya bias-bias dikotomi antara keilmuan agama dan keilmuan umum dalam buku ajar matakuliah PAI di UM yang berjudul Reerientas Pendidikan Isam Meniju Pengenbangan Kepribadian Insan Kamil. Hasil penelitian ini diharapkan dapat dijadikan sebagai bahan evaluasi sekaligus referensi bagi program pengembangannya, yakni pengembangan buku ajar PAI yang dijiwai oleh etos dan nafas reintegrasi epistemologi keilmuan agama (reigias studes) dan umum

${ }^{5}$ Abdullah, IsamicStudesdi Pergunan Tingg: PendkkatanInteegatif-Intekkonkttif(Yogyakarta: Pustaka Pelajar, 2006), 77. ${ }^{6}$ Abdullah, "Kata Pengantar" untuk terjemahan buku Richard C. Martin, Pendkkatan Kajian IdamdalamStudi Agama(Surakarta: Muhammadiyyah University Press, 2001), vi. 
(natural saienes social saienes dan humanities). Buku ajar PAI dengan karakteristik seperti itu nantinya diharapkan akan mampu mengantarkan lahimya aupatyang kritis, analitis, berhorizon luas, dan berjiwa terbuka, bukan sebaliknya mahasiswa yang tidak berkarakter, ekslusif dengan bidang ilmu yang ditekuni, serta mudah menjatuhkan vonis takfir (pengkafiran) terhadap sesamanya yang berbeda pandangan.

\section{Metode Penelitian}

Penelitian ini menggunakan pendekatan kualitatif dengan model studi pustaka (library rearch). Adapun rancangan penelitiannya bersifat deskriptif, yakni uraian secara sistematis dan faktual terhadap bagian-bagian dari text book tersebut yang dikonstruksi dari perspektif dikotomis yang mendistingsikan disiplin keilmuan agama dan keilmuan umum sehingga tidak terjalin keterhubungan secara interdisipliner antara masing-masing rumpun keilmuan. ${ }^{7}$

Sumber data dalam penelitian ini adalah buku ajar matakuliah PAI di UM yang berjudul Recientas Pendidkan Isam Menuju Pengerbangan Kepibadian Insan Kamil yang ditulis oleh tim dosen PAI UM yang berjumlah 11 orang dengan mengacu kepada kurikulum yang diterbitkan oleh Departemen Pendidikan Nasional tahun 2002 tentang Matakuliah Pendidikan Agama Islam (PAI) bagi Perguruan Tinggi Umum (PTU). ${ }^{8}$ Oleh karena penelitian ini menganalisis bias-bias dikotomi antara keilmuan agama dan keilmuan umum dalam text book tersebut, maka sampel penelitian ini adalah teks-teks yang berkaitan dengan bias-bias dikotomi yang ditemukan dalam buku ajar PAI itu.

\section{Pembahasan dan Hasil Penelitian}

Sesuai dengan rumusan masalah yang dikemukakan sebelumnya, bagian ini akan mengidentifikasi bagian-bagian dari buku ajar Reerietasi PendidkanIdam Menju Pengenbangan KepribadianInsanKamil (yang ditulis oleh tim dosen PAI UM tahun 2006) yang mencerminkan paradigma dikotomis. Yakni, materi-materi keislaman yang dikonstruksi di atas paradigma singe entity (dalam arti pengetahuan agama berdiri sendiri tanpa memerlukan bantuan metodologi yang digunakan oleh ilmu pengetahuan umum yang lain), atau di atas paradigma isdated etities (di mana pengetahuan agama tahu keberadaan rumpun keilmuan yang lain, tetapi tidak bersentuhan dan bertegur-sapa secara metodologis).

Tidak keseluruhan dari 13 bab dalam text book tersebut akan diurai satu persatu di sini. Hanya bagian yang teridentifikasi dikonstruk secara dikotomis saja yang akan diuraikan di sini.

a. Framenark Pendidikan Islam: dari Pendekatan D ikotomis-A tomistik Menuju Pendekatan Interdisipliner

Bagian pertama dari buku ajar Reerientasi Penddikan Isam Menuju Pengenbangan Kepribadian Insan Kamil, berdasarkan telaah peneliti, yang mengandung bias dikotomi adalah kata pengantarnya yang berjudul "Framewark Pendidikan Islam". ${ }^{9}$ Peneliti

\footnotetext{
${ }^{7}$ Kathryn H. Au, e. al., Literag Instruction Today. Content Area Reading (New York. Harper Collins College Publishers, 1995), 16.

${ }^{8}$ Periksa A. Manan Idris, 屯. al., Reonietas PenddikanIdam MenujuPengenbanganKeqribadianInsanKamil (Pasuruan: Hilal Pustaka, 2006).

${ }_{9}^{9}$ Idris, e. al., Reerientas Pendidikan Idam viii - x.
} 
mengidentifikasi bahwa paint-paint pemikiran yang diintrodusir di dalamnya berusaha memilah antara konsep keilmuan Islam dan konsep keilmuan Barat. Berikutnya, ada semacam rekomendasi agar keilmuan Islam menjagajarak dari keilmuan Barat yang sekuler. Struktur berpikir model ini sesungguhnya mencerminkan model paradigma isdatedentities, yakni mengetahui disiplin ilmu lain, namun menjaga jarak darinya (agar tidak lebur) bahkan menolak berinteraksi secara metodologis.

Bagian lain dari kata pengantar itu juga menegaskan bahwa tidak ada disiplin ilmu yang netral dan bebas nilai, karena bagaimanapun setiap disiplin ilmu selalu dibangun di atas framenork dan woddkiew tertentu. Perspektif seperti ini jelas kental sekali dengan aroma dikotomi antara keilmuan agama dan keilmuan umum yang divonis sekuler bahkan ateis. $^{10}$

Peneliti berpendapat, bukan eranya lagi disiplin ilmu agama (Islam) menyendiri dan steril dari kontak dan intervensi ilmu-ilmu kealaman (natural scienes), ilmu-ilmu sosial (sodial saiences), dan humaniora. Seorang pakar studi keislaman, Ibrahim Moosa mengisyaratkan perlunya integrasi keilmuan melalui pernyataannya sebagai berikut:

"... having raised the question of international reations, politics, and exonomics, that dbes not mean that schdars of reigion mit, becme econmist or political scietist. Howeer, the study of reigion will suffer if its insight do not take cogizance of how the dscaurse of pditics, economics, and ailture impad on the peformance of religion and vicevice" ${ }^{\prime 1}$

(Terjemahan Indonesia, kurang lebih sebagai berikut). Seorang ahli agama yang mengangkat masalah hubungan internasional, politik dan ekonomi tidak serta-merta harus menjadi pakar politik dan ekonomi. Namun demikian, studi tentang agama [termasuk studi tentang agama Islam] akan sungguh-sungguh menderita, jika pandangan-pandangan dan analisis-analisisnya tidak memahami, mempertimbangkan atau menyertakan sama sekali bagaimana sesungguhnya diskursus tentang politik, ekonomi, dan budaya. Sebab kesemuanya itu mempunyai pengaruh yang sangat luar biasa terhadap tampilan kajian agama, dan begitu pula sebaliknya).

Tegasnya di era globalisasi ini, materi ajar Matakuliah Pendidikan Agama Islam (PAI) tidak boleh lagi menolak untuk bersinggungan dengan disiplin-disiplin ilmu lain yang mengandung muatan ilmu-ilmu kealaman, sosial, dan humaniora kontemporer, seperti: hermeneutik, altural and reigiaus sudies, HAM, sensitivitas gender, filsafat ilmu, dan begitu seterusnya. Jika tidak, mahasiswa akan menderita (suffe) ketika mereka keluar kampus dan berhadapan dengan realitas sosial-kemasyarakatan dan realitas sosialkeagamaan yang begitu kompleks.

Karenanya, muatan-muatan ilmu-ilmu sosial (seperti sosiologi agama dan antropologi agama) serta humaniora kontemporer (seperti teologi pembebasan, HAM dalam Islam, gender issues, ethics, sejarah ilmu pengetahuan, filsafat ilmu pengetahuan, dan seterusnya) harus tampak benar dalam kurikulum dan silabi matakuliah PAI. D engan modal tersebut, setidaknya atpat perguruan tinggi, baik PTU maupun PTAI, ketika kelak memasuki dunia profesi tidak akan terkurung dalam sangkar isdated profession (profesi

\footnotetext{
${ }^{10}$ Ibid., $\mathrm{x}$.

${ }^{11}$ Ebrahim Moosa, "Introduction" dalam Fazlur Rahman, Reival and Reform in Idam A Study of Idamic Fundamentalism(O xford: O ne World Publication, 2000), 28.
} 
yang steril dan terpisah dari persoalan masyarakat di sekitarnya), tetapi mampu berperan sebagai penggagas dan pelopor soial empowement dan soial agent of dangedengan muatan etik yang memihak rakyat kecil yang tidak berdaya (mstadhafun) dan lingkungan hidup yang sehat.

b. Konsep Ketuhanan dalam Islam: Pembuktian Wujud Tuhan Melalui Temuan Sains Modern

"Konsep Ketuhanan dalam Islam" merupakan bab pembuka dari buku ajar Reerietasi Pendidikan Isam Menuju Pengembangan Kepribadan Insan Kamil. Bab pertama ini berisi lima sub bahasan berikut: (1) Prinsip-Prinsip Dasar Epistemologi Islam; (2) Hipotesa tentang Adanya Tuhan; (3) Sejarah Pemikiran Manusia tentang Tuhan; (4) Pembuktian Wujud Tuhan; (5) Munculnya Aliran-Aliran Teologis dalam Islam. ${ }^{12}$

D ari hasil penelaahan mendalam, peneliti mengidentifikasi sub bahasan keempat, yakni Pembuktian Wujud Tuhan (The Argument of God Existance) dikonstruk di atas paradigma singeentity. D alam arti, uraian tentang eksistensi Tuhan hanya didasarkan pada teori-teori klasik yang dikonsepsi oleh filosof-filosof Abad Pertengahan, seperti al-Kindi (w. sekitar 866 M), Ibn Sina (w. 1037 M), dan Ibn Rusyd (w. 1198 M). Model pembuktian seperti itu sama sekali tidak memuaskan manusia modern yang telah memiliki level intelektualitas yang lebih tinggi dari abad-abad sebelumnya. Karenanya pembuktian eksistensi Tuhan dengan menggunakan temuan-temuan sains modern tidak seharusnya diabaikan. D engan demikian, kajian tentang wujud Tuhan tidak hanya dikonstruk di atas paradigma singeentity, tetapi dibangun di atas paradigma interconeted entities yang melibat multidisiplin keilmuan (baca: interdisipliner).

Bukti yang paling jelas perihal adanya Allah Swt adalah ciptaan-Nya, di mana hal itu merupakan hakikat yang paling terang. Bukti ini mendorong kita untuk beriman bahwa tidak diragukan lagi alam ini mempunyai Tuhan. Kita tidak mampu memahami diri kita dan memberikan penafsiran tentang kenyataan alam tanpa adanya iman kepada Allah.

A danya alam dan organisasinya yang menakjubkan serta rahasia-rahasia yang pelik, tidak boleh tidak semuanya memberikan penjelasan bahwa ada suatu kekuatan yang telah menciptakannya, suatu "Akal" yang tidak ada batasnya. Setiap manusia normal percaya bahwa dirinya "ada". A tas dasar itu dan dengan kepercayaan inilah dijalani setiap bentuk kegiatan ilmiah dan kehidupan.

Jika kita percaya tentang eksistensi alam, menurut logika kita harus percaya tentang adanya pencipta alam. Pernyataan yang mengatakan, "Percaya adanya makhluk, tetapi menolak adanya Khaliq" adalah suatu pernyataan yang sama sekali keliru. Kita belum pernah mengetahui adanya sesuatu yang berasal dari tidak ada tanpa diciptakan. Oleh karena itu, bagaimana kita akan percaya bahwa alam semesta yang demikian luasnya itu ada dengan sendirinya tanpa pencipta?

Di sinilah letak urgensi pembuktian wujud Allah dengan pendekatan ilmu-ilmu eksakta, tidak sekedar logika filsafat seperti dalam konsepsi klasik al-Kindi (w. sekitar 866 M), Ibn Sina (w. 1037 M), dan Ibn Rusyd (w. 1198 M) - yang telah dipaparkan pada bab I dari buku ajar Rearientasi Penddikan Isam Menuju Pengembangan Kepribadian Insan Kamil.

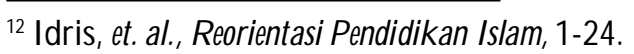


1) Pembuktian Adanya Tuhan dengan Pendekatan Fisika

Sampai abad ke-19 pendapat yang mengatakan bahwa alam menciptakan dirinya sendiri (alam bersifat azali) masih memiliki banyak pengikut. Tetapi setelah ditemukan "Hukum Kedua Termodinamika" (Second Law of Themodinamics) pernyataan tersebut telah kehilangan landasan berpijak.

Hukum tersebut yang dikenal dengan "Hukum Keterbatasan Energi" atau teori "Perubahan Energi Panas" membuktikan bahwa adanya alam tidak mungkin bersifat azali. Hukum tersebut menerangkan bahwa energi panas selalu berpindah dari keadaan panas beralih menjadi tidak panas. Sedangkan kebalikannya tidak mungkin terjadi, yakni energi panas tidak mungkin berubah dari keadaan yang tidak panas menjadi panas. Perubahan energi panas dikendalikan oleh keseimbangan antara "energi yang ada" dengan "energi yang tidak ada".

Sesuai dengan penemuan ilmiah ini, maka "ketidakmampuan proses kerja alam" hari demi hari semakin bertambah dan pada suatu ketika energi panas seluruh benda yang ada akan sama. Pada waktu itu, energi manapun tidak akan ada gunanya bagi kehidupan. Akibatnya akan berakhir semua proses kimia dan fisika, dan dengan sendirinya akan berakhir pula "kehidupan".

Bertitik tolak dari kenyataan bahwa proses kerja kimia dan fisika di alam terus berlangsung serta kehidupan alam tetap berjalan, hal itu membuktikan secara pasti bahwa alam tidaklah bersifat azali. Seandainya alam ini azali, maka sejak dulu alam sudah kehilangan energinya sesuai dengan hukum tersebut, dan tentu tidak akan ada lagi kehidupan di alam ini.

Terkait dengan pembuktian ilmiah ini, Edward Luther Casel menyatakan, "D engan demikian penelitian ilmiah tersebut membuktikan bahwa alam mempunyai permulaan. D engan sendirinya hal tersebut membuktikan pula adanya Tuhan. Sebab segala sesuatu yang mempunyai permulaan tidak mungkin terjadi dengan sendirinya dan tidak boleh tidak alam perlu pada penggerak pertama, yakni Z at Pencipta, Allah" ${ }^{13}$

Sejumlah bukti fisik menunjukkan bahwa alam tidak wujud sejak zaman azali dan alam mempunyai umuryang terbatas. Sebagai contoh, ilmu astronomi membuktikan bahwa alam selalu melebar. Setiap kelompok bintang dan semua benda langit satu sama lain semakin saling berjauhan dengan kecepatan luar biasa. Keadaan demikian memungkinkan kita menerima adanya waktu permulaan bahwa pada waktu itu semuanya saling berkumpul dan bergabung satu sama lain, kemudian mulai muncul gerakan dan panas. Para sarjana menduga bahwa terjadinya alam ini adalah akibat ledakan yang luar biasa sejak 5.000.000.000.000 (5 trilyun) tahun silam.

2) Pembuktian Adanya Tuhan dengan Pendekatan Astronomi

A stronomi menjelaskan bahwa jumlah bintang di langit seperti banyaknya butiran pasir yang ada di pantai seluruh dunia. Bintang tersebut ada yang sedikit lebih besar dari bumi, tetapi kebanyakan sangat besar sekali sehingga satu bintang dapat memuat jutaan bintang seukuran bumi. Alam semesta terdiri dari sekelompok planet-planet dan bintang-bintang yang disebut "gugus bintang" dan semuanya selalu dalam keadaan

${ }^{13}$ Wahid al-D in K han, IdamMejjawabTantanganZaman(Bandung: Pustaka, 1983), 58-59. 
bergerak.

Benda alam yang paling dekat dengan bumi adalah bulan, yang jaraknya dari bumi sekitar 240.000 mil, yang bergerak mengelilingi bumi, dan menyelesaikan setiap gerak edarnya dalam rentang waktu 29 hari sekali. D emikian pula bumi yang terletak 93.000.000.000 mil dari matahari berputar pada porosnya dengan kecepatan 1000 $\mathrm{mil} /$ jam dan menempuh garis edarnya sepanjang $190.000 .000 \mathrm{mi} /$ tahun. Di samping bumi, terdapat gugus 9 planet tata surya, termasuk bumi, yang mengelilingi matahari dengan kecepatan luar biasa.

Matahari tidak berhenti pada suatu tempat tertentu, tetapi ia beredar bersamasama dengan planet-planet dan asteroid mengelilingi garis edarnya dengan kecepatan $600.000 \mathrm{mil} / \mathrm{jam}$. Di samping itu masih ada ribuan sistem selain "sistem tata surya" kita dan setiap sistem mempunyai kumpulan dan galaxy sendiri-sendiri. G alaxy-galaxy tersebut juga beredar pada garis edarnya. Galaxy di mana terletak sistem matahari kita, beredar pada sumbunya dan menyelesaikan gerakan edarnya sekali dalam 200.000.000 tahun cahaya.

Di samping rotasi, terjadi pula gerakan lainnya. Yakni, alam semakin meluas ke segala arah. Matahari kita yang berotasi pada sumbunya juga beredar bersama-sama kita pada bagian luar dari galaxy dan setiap detik semakin menjauh dengan kecepatan $12 \mathrm{mil} /$ detik, sebagaimana halnya gugusan-gugusan bintang yang terdapat dalam sistem bintang kita. D emikian juga semua satelit bergerak pada garis edarnya di samping gerakan khusus bersama sistemnya. Di antaranya ada yang bergerak dengan kecepatan delapan mil perdetik, ada yang dengan kecepatan $33 \mathrm{mil} /$ detik, dan ada pula yang dengan kecepatan $84 \mathrm{mil} /$ detik. Dari contoh tersebut di atas, jelaslah bahwa semua bintang yang ada, setiap detiknya semakin menjauh dari tempatnya semula dengan kecepatan luar biasa. Kecepatan yang luar biasa tersebut bergerak sesuai dengan sistem dan prinsip-prinsip yang teratur. Di antara bintang yang satu dengan bintang yang lain tidak saling bertabrakan dan tidak berubah kecepatannya.

Logika manusia dengan memperhatikan sistem yang luar biasa dan organisasi yang teratur, tentu akan berkesimpulan bahwa mustahil semuanya ini terjadi dengan sendirinya, bahkan akan menyimpulkan bahwa di balik semuanya itu ada kekuatan maha besar yang membuat dan mengendalikan sistem yang luar biasa tersebut. Kekuatan maha besar tersebut adalah Tuhan, Allah swt. ${ }^{14}$

c. Spiritualitas di tengah Tantangan Modernitas: dari Doktrin Teosentris menuju Ajaran Antroposentris

Bagian lain dari buku ajar Rearientasi Pendidikan Islam Menuju Pengembangan Kepribadan Insan Kamil yang teridentifikasi mengandung bias dikotomi karena kajiankajiannya hanya didasarkan atas paradigma singe entity adalah bab III "Keimanan dan Ketakwaan" dan bab IV "Iman dan Takwa: D imensi dan Konsekuensinya" yang dipayungi oleh tema besar "Spiritualitas di tengah Tantangan Modernitas". ${ }^{15}$

${ }^{14}$ Hamdan Mansoer, Stratej PengenbanganMPK, Tidak Dipublikasikan (D irektorat Ketenagaan, Direktorat Jenderal Pendidikan Tinggi, D epartemen Pendidikan Nasional, 2006), 33-37. Periksa juga Hamdan Mansoer, Pembdajaran BełasisKomptend (Implemetas KBK), Tidak D ipublikasikan (Direktorat Ketenagaan, D irektoratJenderal Pendidikan Tinggi, D epartemen Pendidikan Nasional), 11.

${ }^{15}$ Idris, e. al., Reerientas Pendidikan Idam 55-89. 
Alasan peneliti mengidentifikasi kedua bab tersebut sebagai kajian yang singe perspektif (bukan milti perspektif), karena uraiannya hanya didasarkan pada dalil-dalil (baca: teks-teks) agama. Kedua bab tersebut hanya mengeksplorasi aspek normatif dari doktrin keimanan dan ketakwaan dengan mengabaikan dimensi sosiologis dan antropologisnya. Atau dengan kata lain, kajian tentang doktrin keimanan dan ketakwaan lebih bersifat "teosentris" daripada "antroposentris", yakni penekanan lebih untuk mencetak kesalehan ritual yang bersifat individual ketimbang mewujudkan kesalehan sosial yang bersifat komunal. Padahal peran dan fungsi agama yang secara substansial normatif dimaksudkan untuk dijadikan pedoman bagi umat manusia dalam menata dan membangun kehidupan saat ini menghadapi tantangan hebat. Pengakuan dan pelaksanaan ajaran agama kini lebih bersifat memenuhi kewajiban formal, bukan memenuhi kebutuhan batin. Inilah alasan mengapa peneliti mengidentifikasi kedua bab tersebut sebagai kajian yang singeperspektif (baca: berparadigma singeentity), karena uraiannya hanya didasarkan pada dalil-dalil atau teks-teks agama an sich serta kurang mempertimbangkan realitas sosial umat.

Prinsip-prinsip Islam dalam mengubah masyarakat menuju kualitas hidup yang lebih baik harus dipertimbangkan dalam kajian tentang doktrin keimanan dan ketakwaan. Peneliti akan menyebutkan butir-butir yang peneliti anggap prinsipil dan mencerminkan pandangan Islam tentang peranan sosial agama.

Petama, Islam memandang bahwa kehadiran agama di dunia ini dimaksudkan untuk mengubah masyarakat (al-nas) dari berbagai kegelapan kepada cahaya; dari zyllumatkepada al-nue ${ }^{16}$ Meminjam istilah Fathi Yakan (1980), al-Isam Minhaj al-Taghir (Islam adalah agama yang menghendaki perubahan). Ia datang bukan untuk membenarkan status qua, namun ia datang untuk memperbaiki status qua Zxalumatadalah bentuk jamak zhulm (kegelapan atau kezaliman). Ada 3 (tiga) macam zhulm ketidaktahuan tentang syariat, pelanggaran atas syariat Allah, dan penindasan. Islam datang untuk membebaskan mereka dari hidup yang berdasarkan kemaksiatan menuju ketaatan, dari kebodohan tentang syariat menuju pengertian tentang halal dan haram, dari kehidupan yang penuh beban dan belenggu ke arah kebebasan. ${ }^{17}$ Inilah misi Islam, juga misi para nabi serta para penerus nabi- sebagaimana dapat dicermati dari kandungan ayat berikut.

"Orangfarangyangmengkuti Rasul, Nabi yangumm, yangmeika dapatkan temaktub dalam Taurat dan Injil, memeintahkan kepada yang mánuf, melarang merkka dari yang mungkar, menghalalkanyangbaik bag medka, dan mengharankan atas metka yangjedk, danmiepaskan dari medka beban berat dan bedengyrbdengy" 18

Kedua, istilah Islam untuk pembangunan adalah taghir. Prinsip taghyir ditegaskan dengan firman Allah: "Sesungghnya Allah tidak akan mengubah suatu kaumsampai merdka mengubah apayangada pada dir medka" ${ }^{19}$ Islam memandang perubahan sosial harus dimulai dari perubahan individual. Secara berangsur-angsur, perubahan individual ini harus disusul dengan perubahan institusional. Setelah mengajarkan kewajiban Muslim terhadap

${ }^{16}$ Q.S. Ibrahim:1, al-Maidah:15, al-Hadid:9, al-T halaq:10-11, al-A hzab:41-43, dan al-Baqarah:257

${ }^{17}$ Fathi Yakan, Al-Shababva al-Taghir(Beirut: Mu'assasah al-Risalah, 1980), 39.

${ }^{18}$ al-Qur'an, 6 (al-A'raf):157.

${ }^{19}$ al-Q ur'an, 13 (al-Ra'd):11. 
sesamanya, Islam menetapkan institusi zakat. D an, setelah menganjurkan persaudaraan, Islam menetapkan institusi makhat. ${ }^{20}$

Ketiga, Islam memandang bahwa perubahan individual harus dimulai dari peningkatan dimensi intelektual (pengenalan akan syariat Islam), kemudian dimensi ideologikal (berpegang pada kalimat tauhid, termasuk di dalamnya doktrin keimanan dan ketakwaan). D imensi ritual harus tercermin pada dimensi sosial. D alam Islam, shalat selalu dihubungkan dengan kehidupan bermasyarakat; shalat harus mencegah fahsya' dan mungkar. ${ }^{21}$ Shalat selalu dikaitkan dengan zakat dalam banyak ayat al-Q ur'an di mana shalat diperintahkan bersamaan dengan perintah-perintah dalam kehidupan so sial. ${ }^{22} \mathrm{D}$ alam beberapa hadis disebutkan bahwa ibadah yang tidak disertai dengan amal saleh dalam kehidupan sosial tidak akan diterima oleh Allah. Mereka yang tidur kenyang, sementara tetangganya kelaparan. Mereka yang tidur kenyang, sementara tetangganya kelaparan. Mereka yang shalat malam dan berpuasa, tetapi menyakiti tetangganya. Mereka yang beribadah tetapi merampas hak orang lain dan sebagainya, dinyatakan tidak melaksanakan agamanya. Kekurangan dalam ibadah ditebus (kifarat-nya) dengan menunjukkan amal saleh, seperti memberi makan orang miskin, tetapi cacat dalam kehidupan sosial tidak dapat ditebus dengan ibadah ritual. Singkatnya, peneliti berani mengatakan bahwa dimensi sosial ajaran Islam memperoleh proporsi yang jauh lebih besar daripada dimensi ritual atau mistikal..$^{23}$

D emikianlah dalam pandangan Islam, agama seharusnya memegang peranan penting. Islam datang untuk mengubah masyarakat menuju kualitas hidup yang lebih baik, seperti dicerminkan dengan ketaatan yang tinggi kepada Allah, pengetahuan tentang syariat, dan terlepasnya umat dari beban kemiskinan, kebodohan dan sebagainya, serta berbagai macam belenggu yang memasung kebebasan mereka. Islam memandang bahwa pembangunan harus dimulai dengan perubahan individual yang disusul dengan perubahan institusional. Tugas membangun dalam Islam adalah tugas yang mulia, yang tidak jarang melebihi tugas-tugas keagamaan yang bersifat ritual. ${ }^{24}$

d. Sistem Ekonomi Islam: Menjawab Tantangan dan Meraih Peluang

Bagian berikutnya dari buku ajar Reonietas Penddkan Isam Menuju Pengembangan KepribadianInsanKamil yang terindikasi mengandung bias dikotomi adalah bab X II "Sistem Ekonomi Islam", di mana konstruksi teori-teori ekonominya merupakan produk formulasi mazhab Fikih Abad Pertengahan tanpa mempertimbangkan aspek historisitas dan lokalitasnya. A lih-alih menawarkan solusi atas krisis ekonomi kontemporer, konsep-konsep klasik tersebut justru menempatkan umat Islam dalam posisi tanggung: takut (berdosa) meninggalkan teori-teori ekonomi ala fikih klasik, namun canggung untuk berkenalan dengan teori-teori ekonomi modern. ${ }^{25}$

G lobalisasi telah membawa perubahan drastis di segala bidang, tidak terkecuali di bidang ekonomi. Tidak dipungkiri, perkembangan dan kajian ekonomi Islam di Indonesia

\footnotetext{
${ }^{20}$ Yakan, al-Shababua al-Taghir, 45.

${ }^{21}$ al-Q ur'an, 29 (al-Ankabut):45.

${ }^{22}$ al-Qur'an, 70 ( al-Ma'arij):22-28; al-Q ur'an, 108 (al-Ma'un):1-7; al-Qur'an, 2 (al-Baqarah):83.

${ }^{23}$ Jalaluddin Rakhmat, IsamAltematif(Bandung: Mizan, 1998), 41-43.

${ }^{24}$ Ibid., 43-44.

${ }^{25}$ Idris, e.al, Reerientas PendidikanIsam, 267-288.
} 
belakangan cukup marak dan penuh gairah. Hampir setiap waktu selalu ada diskusi, seminar, workshop, dan aktivitas ilmiah lain mengenai ekonomi Islam. Selain itu saat ini, lembaga keuangan Islam juga bermunculan bagai jamur di musim hujan, karena memang ada permintaan (damand) yang tinggi dari masyarakat terhadap lembaga keuangan Islam ini. Pendeknya, ekonomi Islam telah memberikan suatu harapan baru kepada masyarakat kita yang saat ini ekonominya morat-marit. Harapan ini lahir dari keyakinan bahwa Islam itu memang mempunyai sistem ekonomi yang tersendiri, atau mungkin lahir dari rasa jemu terhadap sistem ekonomi yang hanya berpihak pada golongan yang bermodal saja. Apakah harapan ini bisa terpenuhi? Hal itu sangat tergantung pada pencapaian ekonomi Islam dalam membantu dan mengatasi masalah perekonomian di Indonesia.

Sisi inilah yang seharusnya memperoleh proporsi kajian lebih dalam penyusunan materi ajar ekonomi Islam di PTU maupun PTAI. Ironisnya, aspek ini sama sekali tidak terlihat dalam uraian bab XII "Sistem Ekonomi Islam" dalam buku ajar Reanientasi Pendidikan Islam Meniju Pengenbangan Kepribadian Insan Kamil. Melalui telaah mendalam, peneliti menemukan bahwa kajian sistem ekonomi Islam dalam buku tersebut cenderung berorientasi "ke masa lampau" dan justru mengabaikan kondisi "terkini" dari perekonomian umat Islam. Kajian seperti ini merupakan model kajian berparadigma singe entity karena adanya keengganan untuk bertegur sapa dengan perkembangan mutakhir ekonomi Islam.

Saat ini ekonomi Islam lebih cenderung bermakna perbankan Islam. D an, perbankan Islam masih belum bisa keluar dari sistem ekonomi hutang yang diciptakan oleh ekonomi kapitalisme. Walaupun secara teoritis, bank Islam menggunakan kontrak-kontrak atau akad-akad mu'amalah yang bukan hutang, seperti partneship jual beli dan sewa, namun akad-akad hutang jugalah yang paling populer. Hubungan bank Islam dengan nasabahnya masih dirasakan sebagai hubungan kreditor-debitor, yang tidak jauh beda dari bank konvensional. Bank Islam masih berfungsi sebagai moneylendar, dan belum dirasakan sebagai partner atau selleryang sebenarnya. Seakan-akan perbankan Islam hanya berfungsi sebagai variant of capitalism dan bukan its altemative O leh karena itu, bank Islam harus bisa memberikan produk-produk yang memenuhi standar syariat kepada kaum Muslimin dan bukan duplikasi dari bank konvensional. Umat Islam tentunya tidak ingin nama luarnya saja miamalah tetapi isinya adalah duplikasi dari transaksi konvensional.

Secara teoritik, ekonomi Islam juga mencakup unsur-unsur production, consumption, distribution dan bukan hanya exdhange Ekonomi Islam harus membicarakan juga sektor riil, bukan hanya sektor keuangan. Ekonomi Islam juga membahas hal-hal yang bersifat momative, bukan hanya yang positive Ilmu ekonomi Islam, sebagaimana juga ilmu ekonomi konvensional, memiliki bagian hard-core yang tidak bisa diganggu gugat. Hal ini berhubungan erat dengan nilai dan pandangan hidup (wordkien) Islam itu sendiri. Sebagai siene, ilmu ekonomi konvensional lahir dari suasana peradaban Barat untuk menyelesaikan permasalahan peradaban Barat itu sendiri. Jika orang Barat menganggap bunga bank itu baik untuk ekonomi mereka, maka sciene of economics diciptakan untuk menjustifikasi nilai tersebut. Oleh karena itu jika kini umat Islam hendak mengislamkan perbankan, maka mereka harus kembali ke nilainya dulu supaya proses Islamisasi itu sempurna. Jadi tidak cukup dengan yang praktis saja, sementara yang bersifat nilai dan pandangan hidup 
tidak diperhatikan sama sekali.

Epistemologi Islam adalah bagian dari akidah Islam. Maka, mengkonstruk konsep ekonomi Islam yang berdasarkan epistemologi Islam merupakan keharusan. D alam konteks ini pula, sumber ekonomi Islam itu bukan hanya panca indera dan akal semata-mata, tetapi juga ilmu-ilmu yang berasal dari wahyu. Kita mengakui panca indera sebagai sumber ilmu ekonomi. Karenanya kita tidak menolak hukum penawaran dan permintaan (lawof supply and damand), karena hukum ini diambil dari observasi manusia. Kita juga menerima akal sehat sebagai sumber ilmu, karenanya kita juga menerima ilmu-ilmu rasional seperti matematika (statistik, ekonometrik) dalam ekonomi. Tetapi kita juga tidak meninggalkan ilmu yang berasal dari wahyu, seperti larangan riba, perintah berzakat, dan sebagainya. Ekonomi Islam itu lebih kepada ekonomi kebahagiaan (sa'adah) dan bukan menekankan pada ekonomi kekayaan (tsarvah). Yang miskin bisa bahagia sebagaimana juga yang kaya. D an pada saat yang sama, si kaya pun belum tentu bahagia. Berapa banyak negara kaya, tapi tingkat bunuh diri, perceraian, dan anak-anak yang lahir di luar nikah di kalangan penduduknya sangat tinggi.

Kembali kepada epistemologi Islam, ekonomi Islam harus menjadikan epistemologi Islam sebagai landasan ilmunya. Jadi, selain sumber panca indera dan akal, sumber wahyu juga diberikan kedudukan yang sewajarnya dalam ilmu ekonomi. Sehingga nantinya dalam praktik dan kegiatan ekonomi juga akan terlihat pengaruhnya. D alam peradaban Islam dahulu, sistem riba tidak merajalela seperti sekarang ini, karena epistemologi Islam masih berpengaruh kuat. ${ }^{26}$

Menurut hemat peneliti, ilmu ekonomi Islam itu adalah integrasi antara Isamic studes dan eonomics. Studi Islam itulah yang menjadi hard coredan fardu 'ain, sedangkan studi ekonominya menjadi fardukifayah Bukan terbalik, yaitu studi Islam dikritik dengan studi ekonomi. Tetapi studi ekonomi itulah yang harus dikritik dari sudut pandang studi Islam, di mana hal itu juga erat kaitannya dengan epistemologi. Bagi seorang Muslim, ia wajib belajar ilmu-ilmu Islam terlebih dahulu sebelum ilmu-ilmu yang lain. Oleh sebab itu, ada istilah ilmu fardlu 'ain dan ilmu fardu kifayah Yang pertama untuk kebahagiaan diri sendiri, sedangkan yang kedua untuk kebahagiaan masyarakat dan umat. Ilmu akidah, syariat dan akhlak adalah untuk kebahagiaan diri di dunia dan akhirat, sementara ilmu ekonomi adalah untuk kebahagiaan masyarakat di dunia ini khususnya.

A khirnya, pemaduan ilmu-ilmu agama yang bersumber dari wahyu dengan ilmuilmu humaniora seperti ekonomi, adalah sebuah keharusan. Ilmu agama itulah yang sepatutnya memimpin ilmu ekonomi, dan bukan sebaliknya. D ulu, ketika peradaban Islam pada posisi yang tinggi, al-G hazali mencanangkan ihya' 'ulumal-dn yaitu menghidupkan kembali ilmu-ilmu agama yang hampir tenggelam dalam filsafat Yunani. Kini, ketika peradaban Barat menghegemoni, umat Islam lebih butuh lagi pada ihya' 'ulumal-dnuntuk menyaring arus ilmu-ilmu modern yang memasuki negeri-negeri Muslim. Oleh sebab itu seperti dikatakan oleh Prof. Naquib al-Attas, umat Islam kini perlu melakukan devesterization of knowkeege ${ }^{27}$

${ }^{26}$ Ugi Suharto, "Ekonomi Islam Harus Berbasis Epitemologi Islam" dalam MajalahPerikirandanPeradabanIsam ISLAMIA, Tahun II, Nomer 5 (Jakarta: Khoirul Bayan, 2005), 100-103.

${ }^{27}$ Ibid. 


\section{Penutup}

Bukan eranya lagi disiplin ilmu agama (Islam) menyendiri dan steril dari kontak dan intervensi ilmu-ilmu kealaman, ilmu-ilmu sosial, dan humaniora. Karenanya, kesadaran untuk membenahi dan menyembuhkan "luka-luka dikotomi" keilmuan umum dan keilmuan agama yang makin hari kian menyakitkan merupakan tuntutan yang mendesak.

Rekomendasi tersebut didasarkan oleh beberapa alasan berikut. Petama, silabus Matakuliah Pendidikan Agama Islam (PAI) yang dikembangkan di Perguruan Tinggi Umum (PTU) masih mencerminkan paradigma dikotomis-atomistik di atas. Setidaknya penelitian ini membuktikan hal itu. Kedua, studi tentang agama (termasuk Matakuliah PAI di PTU) akan sungguh-sungguh menderita (sffer), jika pandangan-pandangan dan analisis-analisisnya tidak memahami, mempertimbangkan atau menyertakan sama sekali bagaimana sesungguhnya diskursus tentang politik, ekonomi, sosial, budaya, dan seni. Sebab aspekaspek tersebut memiliki pengaruh yang luar biasa terhadap tampilan matakuliah PAI, dan begitu pula sebaliknya.

\section{Dafar Rujukan}

Abdullah, M. Amin. Islamic Studies di Pergunan Tingg: Pendkkatan Integratif-Intekkondktif. Yogyakarta: Pustaka Pelajar, 2006. . "Kata Pengantar" untuk terjemahan buku Richard C. Martin, PendkatanKajian Islamdalam Studi Agama. Surakarta: Muhammadiyyah University Press, 2001. . "D esain Pengembangan Akademik IAIN Menuju UIN: Dari Pendekatan Dikotomis-A tomistik ke Integratif-Interkonektif" dalam Fahruddin Faiz (ed). Isamic StudiesdalamParadigma Integrasi-Intekknkks: SebuahAntdog. Yogyakarta: Penerbit SUKA Press, 2007.

Arkoun, Mohammed. Tarikhiyyatal-Fikral-'Arabyal-Isamy. Ter. Hashim Salih. Beirut: Markaz al-Inma' al-Q awmiy, 1986.

Au, Kathryn H, Mason, Jana M., dan Schen, Judith A. Literacy Instrution Today. Contert Area Reading New York: Harper Collins College Publishers, 1995.

Baum, G regory. Agama Dalam BayangBayang Irdativisme Sebuah Analisis Sosidog Pengtahuan Karl Marnhim Tentang Sintesa Kebenaran HistorisNomatif. Ter. Achmad Mustajib e. al. Yogyakarta: PT. Tiara Wacana, 1999.

Idris, Manan. dkk. Reonietasi Penddkan Idam Menju Pengenbangan Kepribadian Insan Kamil. Pasuruan: Hilal Pustaka, 2006.

Khan, Wahid al-D in. Isam Mejaanab Tantancan Zaman Bandung: Pustaka, 1983.

Mansoer, Hamdan. Strateg Pengembangan MPK. Direktorat Ketenagaan, Direktorat Jenderal Pendidikan Tinggi, D epartemen Pendidikan Nasional. (Tidak Dipubikasikan), 2006. . Penbdajaran Berbasis Komptens (Implementasi KBK). Direktorat Ketenagaan, Direktorat Jenderal Pendidikan Tinggi, D epartemen Pendidikan Nasional. (Tidak Dipublikasikan), 2006.

Moosa, Ebrahim. "Introduction" dalam Fazlur Rahman, Reival and Refomin Islam A Study of Idamic Fundamentalism Oxford: One World Publication, 2000.

al-Na'im, Abdullahi A hmed. Toward an Isamic Refomation Civil Liberties, Human Right and Intemational Law New York: Syracuse University Press, 1990. 
Rakhmat, Jalaluddin. IdamAltematif. Bandung: Mizan, 1998.

Suharto, Ugi. "Ekonomi Islam Harus Berbasis Epitemologi Islam" dalam Majalah Perikiran dan Peadaban IslamISLAMIA (Tahun II, Nomer 5). Jakarta: Khoirul Bayan, 2005.

Yakan, Fathi. Al-Shabab wa al-Taghir. Beirut: Mu'assasah al-Risalah, 1980. 